\title{
A Review of Nigerian Metallic Minerals for Technological Development
}

\author{
Umar Saidu Bamalli *, Ali Moumouni**, Mohammed Suleiman Chaanda*** \\ *Raw Material and Development Council, Abuja, Nigeria; ** Department of Geology and Mining, Nasarawa State University, Keffi, \\ Nigeria; ***Department of Earth Sciences, Federal University of Petroleum, Effrun, Nigeria. \\ Email: usbamalli@hotmail.com, alimoumouni2005@yahoo.fr, chaanda05@yahoo.com
}

Received December $4^{\text {th }}, 2010$; revised March $4^{\text {th }}$, 2011; accepted March $17^{\text {th }}, 2011$.

\begin{abstract}
The metallic mineral resources of Nigeria have not been fully appraised due to lack of sufficient studies and technology. Previous works identified a number of minerals deposits which have remained largely unevaluated. Some known deposits were confirmed while new ones were identified and documented. The metallic minerals found in Nigeria include iron ore (with over 3 billion metric tones), ferro-alloy minerals (manganese, vanadium, nickel, chromite, columbite, molybdenum, zircon, wolfram/tungsten tourmaline and tantalite), tin ore (cassiterite), lead/zinc, niobium, uranium ore and precious metal (Gold). Looking at the diversity of the mineral types and industrial importance of most of them and the need to exploit and process the minerals for technological development, there is need to build up capability to produce efficient unit operations of the required sizes by indigenous manufacturers.
\end{abstract}

Keywords: Metallic Minerals, Technology, Nigeria

\section{Introduction}

It has been proven that Nigeria is endowed with a lot of mineral resources. The range of mineral raw materials and their reserves are so wide that it should not have been necessary to import industrial mineral raw materials. Though, the primary mineral can be exploited for Industrial processing, many industries import their mineral raw materials requirements due mainly to inadequate technology for transforming raw materials into variety of products needed by local industries.

Nigeria, in pursuing the goal of adding value to her metallic mineral ores, had adopted the mono-cultural approach which seems to dominate our economic activeties. We as people always bemoan our economy which is precariously based on a mono-product, petroleum. In our endeavour to tap our metallic mineral resources, we also became fixated on one metal mineral-iron ore. While the developed countries are able to exploit their mineral resources efficiently, the developing countries are faced with inadequate capital and a lack of required technology, such that their dependency on the developed countries is inevitable.

\section{Geological Setting and Occurrence of Metallic Minerals in Nigeria}

The surface area of Nigeria 923,768 sq. km is covered in nearly equal proportions by crystalline rocks and sedimentary rocks. As a result of nearly 100 years of geological studies, geological and other related maps, such as structural/tectonic, minerals, and mines maps have been produced. From these, the relationship between geology and economic minerals deposits/occurrences is clear. The crystalline rocks are further divided into three main groups viz:

- The Basement Complex

- The Younger Granites

- Tertiary - Recent Volcanics

The sedimentary rocks are distributed over into sedimentary basins which include: The Lower Benue Basin, the Middle Benue basin, the Upper Benue (Gongola and Yola Arms), the Anambra Basin, the Bida Basin, the Sokoto Basin, the Chad (Bornu) Basin, the Dahomey Basin and the Niger Delta Basin. Within the sedimentary basins are found a large variety of industrial minerals such as limestone, salt, clay, gypsum, barites, and energy raw materials like coal, oil, gas, and bitumen. Also the sediments hosted non-ferrous base metals such as lead and zinc occurring in veins (Rahaman, 2003).

This favourable geological setting harbours a wide va- 
Table 1. Iron ore reserves in Nigeria

\begin{tabular}{ccccccccccc}
\hline Location & $\mathbf{F e}$ & $\mathbf{F e}_{\mathbf{2}} \mathbf{0}_{\mathbf{3}}$ & $\mathbf{S i O}_{\mathbf{2}}$ & $\mathbf{A l}_{2} \mathbf{0}_{\mathbf{3}}$ & $\mathbf{C a O}$ & $\mathbf{M g O}$ & $\mathbf{P}_{\mathbf{2}} \mathbf{0}_{\mathbf{5}}$ & $\mathbf{M n O}$ & $\mathbf{T i \mathbf { O } _ { 2 }}$ & Reserved (tonnes) \\
\hline Agbaja & $45-54$ & 62.64 & 8.55 & 9.60 & 0.72 & 0.38 & 4.16 & 0.14 & 0.37 & 2 billion \\
Itakpe & $38-45$ & 53.10 & 44.80 & 1.00 & 0.30 & 0.20 & 0.05 & 0.05 & 0.10 & $200-300$ million \\
Ajabanoko & 35.61 & 47.74 & 0.41 & & & & 0.11 & 0.05 & 0.06 & 30 million \\
Chokochoko & 37.43 & 47.65 & 4.30 & & & & 0.05 & 0.52 & 70 million \\
Agbade Okudu & 37.43 & 29.41 & 0.62 & & & & & & 70 million \\
Nsude Hills & 37.43 & & & & & & & & & 60 million \\
\hline
\end{tabular}

Source: Inventory of Nigerian Minerals, Mines and Miners (1993).

riety of minerals which constitute veritable raw materials for diverse industries, huge quantities of vital minerals such as iron-ore, semi precious minerals, tin, lead-zinc, columbite and ferro-alloy deposits found in traces in different locations in the country.

\section{Raw Materials Availability Locally}

Metallic minerals, so far discovered in Nigeria include iron ore, cassiterite, columbite, lead/zinc ores, and ferroalloy deposits found in traces in different locations in the country.

\section{Iron Ore}

Many deposits of iron-ore have been found in the country. The types of deposit discovered include haematite-magnetite, haematite-geothite and siderite-geothite. The deposits are abundant in Kwara, and Kogi States. Other States where iron ore occurrences have been discovered include Nasarawa, Sokoto, Kaduna, Oyo, Osun, Bauchi, Borno and Benue. There are over 3 billion metric tonnes of iron ore deposits in the country. Table 1 shows Nigeria's iron ore reserves. Other deposits of iron ore in the country are still under investigation as shown in Table 2.

\section{Ferro-Alloy Minerals}

Ferro-Alloys are alloying agents, which are added to molten iron to obtain desirable properties in steel. They may deoxidize the molten metal, control grain growth, neutralising the deleterious effect of non-metallic inclusions, increase metallic resistance to corrosion, improve toughness, strength and wear resistance. Below is a Table 3 , showing the locations of the various ferro-alloy deposits in the country. Columbite, tantalite and zircon which are allied minerals in most alluvial tin fields and therefore are by-products of tin exploitation, while other ferro-alloy minerals deposits are yet to be fully explored and delineated.

\section{Tin Ore (Casseterite)}

Prior to the discovery of oil in Nigeria, the major revenue and source of foreign exchange for the country was from
Table 2. Iron ore reserves under investigation

\begin{tabular}{ccc}
\hline LOCATIONS & STATE & IRON CONTENT (\%) \\
\hline Muro Hills & Nasarawa & $25-30$ \\
Dakingari & Kebbi & $22-52$ \\
Tajimi & Kaduna & $22-52$ \\
Rishi & Bauchi & $14-19$ \\
Karfa & Borno & $34-45$ \\
Eginija & Benue & $34-45$ \\
\hline
\end{tabular}

Source: Inventory of Nigerian Minerals, Mines and Miners (199)3.

Table 3. Ferro-alloy mineral deposits in Nigeria

\begin{tabular}{|c|c|c|}
\hline MINERAL & LOCATION & STATUS \\
\hline Manganese & Mallam Ayuba, Zaria & $\begin{array}{l}\text { To be fully investi- } \\
\text { gated }\end{array}$ \\
\hline Vanadium & Abuja & To be investigated \\
\hline Nickel & Ife-Ilesha & To be investigated \\
\hline Chromite & Sokoto and Katsina & To be investigated \\
\hline Columbite & $\begin{array}{c}\text { Plateau,Nasarawa Kaduna, } \\
\text { Kano, Abuja, Ondo, Kwara } \\
\text { and Bauchi States }\end{array}$ & $\begin{array}{l}\text { Some deposits are } \\
\text { being exploited }\end{array}$ \\
\hline Molybdenum & $\begin{array}{c}\text { Plateau,Nasarawa, Bauchi, } \\
\text { and Ondo States }\end{array}$ & $\begin{array}{l}\text { To be further inves- } \\
\text { tigated }\end{array}$ \\
\hline Zircon & $\begin{array}{l}\text { Nasarawa, Bauchi, Kaduna } \\
\text { and Ondo States }\end{array}$ & $\begin{array}{l}\text { By-product of cas- } \\
\text { seterite beneficiation }\end{array}$ \\
\hline Wolfram/Tungsten & $\begin{array}{c}\text { Nasarawa,Bauchi, Kano and } \\
\text { Kaduna }\end{array}$ & To be investigated \\
\hline Tourmaline & $\begin{array}{c}\text { Kaduna, Nasarawa,Plateau \& } \\
\text { Kwara States }\end{array}$ & $\begin{array}{l}\text { To be fully investi- } \\
\text { gated }\end{array}$ \\
\hline Tantalite & $\begin{array}{c}\text { Plateau, Bauchi, FCT, Nassa- } \\
\text { rawa, Kaduna and Ondo } \\
\text { States }\end{array}$ & $\begin{array}{l}\text { By-product of cas- } \\
\text { seterite beneficiation }\end{array}$ \\
\hline
\end{tabular}

tin mining operation. The mining industry comprised a large number of foreign companies with small-scale indigenous miners. During the tin boom era of the $50 \mathrm{~s}$, production hit the 12,000 tonnes/annum mark (Table 4 and Figure 1). However, due to the depletion of subsurface deposits, production cost had gone up and this, coupled with the downturn of world tin price, resulted in the nation's tin production to an all time low level.

From the geological evidence, there are extensive casseterite deposits lies buried under basalt and volcanic flows particularly in Plateau, Bauchi, Nassarawa, FCT, Kano, Kaduna, Kwara, Kogi, Ondo and Osun States.

There is a law banning the exportation of casseterite and a lot is being smuggled out of the country due to lack 
Table 4. Tin in concentrate (Long Tons)

\begin{tabular}{ccccccccc}
\hline S/N & 1 & 2 & 3 & 4 & 5 & 6 & 7 & 8 \\
\hline Year & 1901 & 1902 & 1903 & 1904 & 1905 & 1906 & 1907 & 1908 \\
Tin & - & - & 6 & 5 & 2 & 12 & 145 & 384 \\
S/N & 9 & 10 & 11 & 12 & 13 & 14 & 15 & 16 \\
& 1941 & 1942 & 1943 & 1944 & 1945 & 1946 & 1947 & 1948 \\
Tin & 12,256 & 12,601 & 12,683 & 12,712 & 11,403 & 10,498 & 9,279 & 9,384 \\
S/N & 17 & 18 & 19 & 20 & 21 & 22 & 23 & 24 \\
& 1971 & 1972 & 1973 & 1974 & 1975 & 1976 & 1977 & 1978 \\
Tin & 7,326 & 6,737 & 5,828 & 5,455 & 4,652 & 3,710 & 3,267 & 2,751 \\
\hline
\end{tabular}

Source: (After Ifaturoti, 1994)

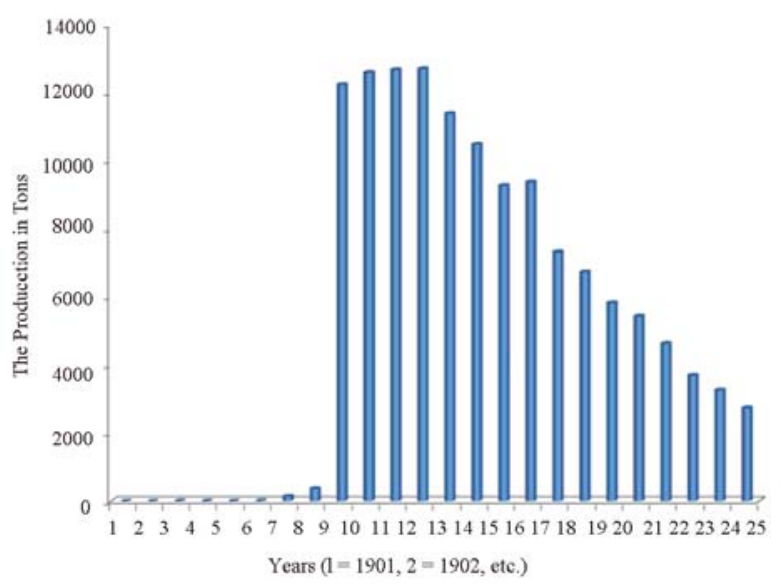

Figure 1. Tin production in Nigeria between 1901-1978

of company to smelt the ore to produce ingots.

\section{Lead and Zinc Ores}

Lead and zinc deposits occur in rock of Lower Cretaceous age. They are all telethermal in type and originated from low temperature hydrothermal solutions associated with recent volcanism. Major deposits of lead and zinc have been found in Nigeria; mineralisation is observed along a belt some 30 - 50 kilometres wide and extended approximately 560 kilometres narrow belt extending from Ishiagu in Ebonyi State through Benue, Adamawa, Taraba, Nasarawa and Plateau States to Bauchi State. Occurrences are known at Ameka, Ameri and Enyigba, near Abakaliki at Arufu in Benue, Zurak and Gwana in Bauchi States.

\section{Niobium Ores}

The Younger Granite Complex of the Jos Plateau is rich in columbite (the mineral from which Niobium can be extracted). Columbite was mined as by-product in the mining of tin. The metal has a wide application for making ferro-alloy where qualities of toughness and shock resistance are desired. Between 1940 and 1956, Nigeria accounted for $95 \%$ of the Niobium consumed in the world industry (Ifaturoti, 1994).

Niobium and Tantalum ores are usually found together.
The most important minerals are the mixed iron-manganese niobotantalate-niobite and tantalite, which share the formula (FeMn) ( $\mathrm{Nb} \mathrm{Ta})_{5} \mathrm{O}_{6}$. Niobite may contain up to $34 \% \mathrm{Ta}_{2} \mathrm{O}_{5}$ and tantalite up to $27 \%$ of $\mathrm{Nb}_{2} \mathrm{O}_{6}$. Most other minerals are equally complex and mixed, the next importance being a series between pyrochlore and microlite. Distribution is widespread in mineralised regions but very sparse. Niobite is found with tin in Nigerian mines. In Nigeria, iron-manganese niobotantalate ores occur largely in Jos-Bukuru areas of Plateau State (Ogbonna et al., 1999), the Rop complex, and in the Afu Ring Complex in Nasarawa State. They occur in the granitic rocks and pegmatites associated with quartz, feldspar and beryl.

From the Table 6 above, the Rayfield Gona site has the richest deposit of columbite ore reaching a maximum content of $11.2 \mathrm{Ibs} /$ tons.

As a result of its occurrence as an accessory mineral, the bulk of the columbite is extremely fine grained (Beus, 1980). A few exceptionally large crystals may be up to $5 \mathrm{~mm}$ in length but by far the greater majority is fine about 60 microns. Most of the columbite has a platly or particular habit in crystallisation. In all however, the Nbo/TaO ratio especially in the Younger Granite columbite is always in excess of 5.1 .

\section{Uranium Ores}

The Uranium deposits have been located in Cross River, Bauchi, Adamawa/Taraba, Plateau and Kano States. Pyrochlore, which contains 3.3\% uranium oxide, 3.3\% thorium oxide and $41.1 \%$ niobium and tantalum occur in Ririwai hills in Kano State.

\section{Precious Metals}

Gold is the only precious metal that has been produced in Nigeria. The main areas of mining were Malele, Malendo in Zamfara and Sokoto States; Ife/Ijesha in Osun State; Minna and Suleja in Niger State, Okolom in Kogi State, Birnin-Gwari and Kurmin Gemana in Kaduna State.

\section{Classification of Metallic Minerals Available in Nigeria}

1. Metallic minerals being exploited now are: Tin, Columbite, Gold

2. Metallic minerals whose reserves have been estimated are: Illmenite, Lead/Zinc

3.Metallic minerals whose occurrences are known are: Wolfram, Molybdenum, Copper

a) There is only one precious mineral i.e. Gold, Silver is found in small quantities

b) The minerals that produce the non-ferrous metals are Casseterite, Galena and Sphalerite 
Table 5. Location of Lead/Zinc deposit in Nigeria

\begin{tabular}{cccc}
\hline State & LGA & Location & Status \\
\hline Ebonyi & Ikwo-Abakaliki & Ameri-Ameka & Dormant mine \\
Ebonyi & Ikwo-Abakaliki & Enyingba & $\begin{array}{c}\text { Dormant mine high } \\
\text { prospect }\end{array}$ \\
Ebonyi & Ivo & Ishiagu & Active mine \\
Ebonyi & Izzi & Mkpome & Active \\
Cross River & Ogoja & Wanakande Gabu & High prospect \\
Bauchi & Alkaleri & Gwana & Prospect \\
Plateau & Wase & Zurak & Dormant high pros- \\
& & & pect \\
\hline
\end{tabular}

Source: (RMRDC, 2005)

Table 6. Primary columbite values in some local biotite-granite rocks

\begin{tabular}{cccc}
\hline $\begin{array}{c}\text { Complex } \\
\text { Granite }\end{array}$ & $\begin{array}{c}\text { Jos-Bukuru } \\
\text { Columbite } \\
\text { (Ibs/ton) }\end{array}$ & Granite (Ibs/ton) & $\begin{array}{c}\text { Rop Complex } \\
\text { Columbite }\end{array}$ \\
\hline Sano-Gari & $0.08-0.17$ & Kaskara & 0.12 \\
Bukuru & $0.18-0.23$ & Bukuru-Bukwai & - \\
Delimi & $0.14-0.16$ & Microgranite & 0.22 \\
Rayfield Gona & $0.48-11.2$ & Bukka-Bukwai & $0.05-0.95$ \\
Kuru Stock & $0.25-0.35$ & Ganna-Micogranite & $0.02-0.05$ \\
N’Gel & $0.13-0.19$ & Ganna & $0.07-0.12$ \\
Jos & $0.02-0.06$ & Kwop & Trace \\
\hline
\end{tabular}

Source: (Ogbonna, 1999)

c) The minerals that produce iron and ferro-alloys are: Iron ore, Molybdenite and Tungsten

d) Minerals that produce minor metals are: Beryl, Monazite, Tantalum, Columbite, Rutile, Illmenite

\section{Industries Utilising Metallic Minerals Available in Nigeria}

a) Ajaokuta steel and Delta steel

b) Non-ferrous industries

Makeri Smelting has started utilising tin to produce solders 41.74 tpa, Sn and car wheel balance weight$95.82 \mathrm{t}-\mathrm{Pb}$ are now being used for the purpose. There is no smelter for lead and zinc. Therefore all lead and zinc used in the country is imported.

c) Vehicle assembly plants

Batteries - lead the mineral are known to occur but not yet exploited.

d) Electrical and electronic industries

These are assembly type operations and all materials that utilise minerals available in Nigeria are imported e.g. condensers, cathode, in x-ray tubes, radio but solders are produced from local tin are not used in electronics.

When the internal consumption of minerals available in Nigeria is compared with other uses that the mineral could be put to, it is very clear that:

a) Minerals are not fully harnessed for industrial development in Nigeria.

b) Mineral development is so slow because of inadequate funding and also lack of awareness on the impor- tance of the minerals in industrial development. If this trend continues then there is little hope of fully harnessing the mineral resources fully for industrial and technological development.

Effort is being made to utilise the minerals and also to speed up exploration and exploitation of the known mineral occurrence.

\section{Technology Acquisition in Metallic Min- erals}

Many technological goods such as processing equipment and their components have to be imported. Their importation does not imply technology acquisition in the real sense because the country cannot immediately adapt, manage and generates its technologies from them. However, the influence of the goods is an inevitable stage in the multiplicity of stages leading to the acquisition of technology.

Acquisition of technology will be encouraged by:

- Exposure of staff e.g. artisans, technicians, engineers, fabricators

- Increase level of funding

- Provision of incentives by government

- People's genuine interest in science, engineering and technology as opposed to buying and selling

- International cooperation

There is need to build up capability to produce efficient unit operations of the required sizes by indigenous manufacturers.

\section{Science and Technology Policy}

The policy paid some attention to minerals with the objective of producing and guaranteeing a steady supply of raw materials from nation's resources, for the productive sector of the economy. It recommends exploration and exploitation of resources. It proposes encouragement of development of programmes that promote use of local raw materials, programme for promotion and adoption of processes for converting local resources to suitable forms as substitutes for industrial raw materials and programmes for developing new and alternate materials to provide materials for developing new technologies. The impact of the policy has not been felt in the mineral sector.

To promote the policy, the following are recommended:

a. A well equipped testing and processing laboratory with all known sophisticated testing facilities for physiccal and chemical properties of mineral processing technology and equipment design.

b. Research on miniature smelters of $1 / 2$ ton capacity, so that minerals that do not occur in abundance could be smelted to meet local consumption. 
c. Industries should be encouraged to carry out research and development, also to sponsor research.

d. High wages to encourage indigenous engineers will increase innovations and invention.

e. Research activities should be done according to demands by the economy rather than for academic purposes.

\section{Conclusions}

Nigeria is well endowed with metallic minerals which include iron ore, cassiterite, columbite, lead/zinc ores, and ferro-alloy deposits found in traces in different locations in the country. However the minerals are not fully harnessed for industrial development in Nigeria, also the mineral development is so slow because of inadequate funding and also lack of awareness on the importance of the minerals in industrial development. If this trend continues then there is little hope of fully harnessing the mineral resources fully for industrial and technological development. This paper has reviewed the occurrences of Nigerian metallic minerals in order to motivate government (policy makers) and investors to put more interest towards developing such important resources.

\section{REFERENCES}

[1] A. A. Beus, "Studies of Minerals Deposit,"4th edition,
MacGraw-Hill, London, 1980, pp. 19-45.

[2] A. D. Famuboni, "Sourcing of Raw Materials for the Nigerian Iron and Steel industries,” Distinguished lecture presented at Dept. of Mining Engineering, Kaduna Polytechnic, Kaduna, 1990.

[3] E. A. Ifaturoti, "Stable Administration and Mineral Resources Development," Nigerian Mining and Geosciences Society Newsmagazine, Vol. 94, No. 2, 1995, pp. 10-23.

[4] Inventory of Nigerian Minerals, Mines and Miners, Publication of the Federal Ministry of Petroleum and Mineral Resources, 1993, pp. 1-29.

[5] Multi-disciplinary Committee of the Techno-economic survey on base metal, iron and steel and engineering services sector ( $4^{\text {th }}$ update), 2003.

[6] A. I. Ogbonna, S. M. Nwakaudu and O. O. Onyemaobi. "Strategic Mineral Deposits in Nigeria: The Neglected case of Niobotantalates.” Proceedings of the 16th Annual Conferenc of the Nigerian Metallurgical Society, Abuja, 1999.

[7] Raw Materials update, A Bi-annual publication of the Raw Materials Research and Development Council, Vol. 6, No. 1, 2005, p. 9.

[8] N. A. Yakubu, E. O. Damisa and I. S. Amoka, "Resuscitation a Dying Hope: The Case of Ajaokuta Steel Project," Nigerian Mining Journal, Vol. 3, No. 1, 1999, pp. 54-57. 